\title{
Vitamin D receptor gene polymorphism and risk of skin cancer patients of Kashmiri population (India): A case-control study
}

\section{Jasiya Qadir ${ }^{1}$, Sabhiya Majid ${ }^{2}$, Fouzia Rashid ${ }^{3}$, Iffat Hassan 4 , Peerzada Sajad 4 , Yasmeen Jabeen Bhat ${ }^{4}$, Inshah Din', Arif Akbar Bhat ${ }^{1}$, Hilal Ahmad Wani ${ }^{5}$, Rabia Farooq ${ }^{1}$}

${ }^{1}$ Department of Biochemistry, Government Medical College, Srinagar, India, ${ }^{2}$ Department of Biochemistry, Government Medical College (Research Centre University of Kashmir), Srinagar, Kashmir India, ${ }^{3}$ Department of Clinical Biochemistry, University of Kashmir, Srinagar, India, ${ }^{4}$ Department of Dermatology, Government Medical College Srinagar, India, ${ }^{5}$ Multidiscilinary Research Unit, Government Medical College, Srinagar, India

Corresponding author: Prof. Sabhiya Majid, E-mail: sabuumajid@gmail.com

\begin{abstract}
Background: Vitamin D deficiency and Vitamin D Receptor (VDR) polymorphism, Fokl, is reported to be associated with the increased risk of several types of cancers through the regulation of various cancer related signaling pathways. We aimed to determine the effect of vitamin D deficiency and the association of FoklVDR gene polymorphism with the risk of skin cancer in Kashmiri population. Material and Methods: A case-control study was conducted that include 68 histopathologically confirmed cases of skin cancer and 65 normal healthy controls from Kashmiri population. Vitamin D levels were estimated by automated chemiluminescent microparticle immunoassay. The Fokl genotyping was done by polymerase chain reaction-restriction fragment length polymorphism (PCR-RFLP) technique followed by sequencing of amplified PCR products. Result: We detected (T/C) polymorphism in the first potential start (ATG) codon in exon 2 of VDR gene. The frequencies of CC, CT and TT genotypes among the cases were $33.82 \%, 47.06 \%$ and $19.11 \%$ while in controls genotypic frequencies were $53.84 \%, 38.46 \%$ and $7.7 \%$ respectively. A significant difference was observed in variant allele frequencies $(C T+T T)$ between the cases and controls with odds ratio $=2.283 ; 95 \%$ confidence interval $=1.133-4.597(P=0.02)$. Interestingly, the association of CT and TT genotype was observed statistically significant among the squamous cell carcinoma $(\mathrm{SCC})(P<0.05)$ and insignificant among basal cell carcinoma $(P>0.05)$. The plasma 25(OH)D levels were significantly low among the cases as compared to healthy controls $(\mathrm{P}<0.05)$. Conclusion: We found the possible role of vitamin $\mathrm{D}$ deficiency and Fokl VDR polymorphism with the increased risk of skin cancer. The Fokl polymorphism appears to be a strong risk factor for SCC development in Kashmiri population.
\end{abstract}

Key words: Vitamin Dkwd; Fokl polymorphism; Skin cancer; SMHS

\section{INTRODUCTION}

Globally, skin cancer is one the most commonly diagnosed type of cancer in humans [1]. It accounts for around $40 \%$ of cancer cases $[2,3]$. The rate of incidence is low in India as compared to the western world. However, due to its large population, the absolute number of cases is estimated to be significant [4]. The most common types of skin cancers may be categorized into two major groups: melanoma and non-melanoma. Non-melanoma type of skin cancer (NMSC) arises from keratinocytes and is further divided into two subtypes: basal cell carcinomas (BCC) and squamous cell carcinomas (SCC). Globally, BCC is the most common type of skin cancer accounting for approximately $70 \%$ of all malignant diseases of the skin [5]. Various studies have consistently reported that SCC is the most prevalent type of skin cancer in India [4,6-8]. Reports

\footnotetext{
How to cite this article: Qadir J, Majid S, Rashid F, Hassan I, Sajad P, Bhat YJ, Din I, Bhat AA, Wani HA, Farooq R. Vitamin D receptor gene polymorphism and risk of skin cancer patients of Kashmiri population (India): A case-control study. Our Dermatol Online. 2018;9(3):233-240.

Submission: 28.10.2017; Acceptance: 04.01.2018

DOI: 10.7241 /ourd.20183.2
} 
also indicate that skin cancer especially non-melanoma skin cancer (NMSC) is on rise in India [9]. However, clinical spectrum of skin cancer in Kashmir valley bears a different tale from the rest of the country due to its geography, climate, dietary habits and socio culture. The incidence of NMSC in Kashmir valley among males and females has been reported to be $2.7 \%$ and $2.8 \%$ respectively [10]. Genetic as well as environmental factors play an important role in the development of cancers [11- 13]. Strong associations has been observed between the deficient circulating levels of vitamin $D$ and increased risk of various types of cancers like breast, colon, $[14,15]$ and ovarian $[16,17]$. Kashmiri people are prone to vitamin D deficiency due different topographical, geographical and climatic conditions [18]. Association between vitamin D levels and risk of skin cancer have been examined in several studies and provide an insight into the positive role of vitamin D deficiency in the development of skin cancer especially NMSC.

Vitamin D modulates various cancer related signaling pathways and acts via binding to its intranuclear receptor vitamin $\mathrm{D}$ receptor (VDR) there by altering the gene expression of various proteins involved in the process of proliferation, differentiation and regulation of cell cycle [19]. VDR contributes to the signaling of hedgehog $(\mathrm{Hh})$ and $\mathrm{Wnt} / \beta$-catenin pathways that plays an important role in proliferation and differentiation of keratinocytes [20]. Several studies have reported that VDR gene is significantly associated with the frequency of occurrence of various types of cancers [19]. VDR is encoded by a large gene (>100kb) located on chromosome 12ql2-ql4 [21]. Whereas Fokl polymorphism, (rs2228570) is present at the first potential site start in exon 2 of the VDR gene [22-25]. This polymorphism alters an ACG codon that is located ten base pairs upstream from the translation start codon and results in the generation of an additional start codon. A change in the sequence from $C$ to $T$ allele in the translation site leads to generation of a polymorphic variant (TT). If the initiation of translation starts from this alternative site (thymine variant), the resultant product is three amino acid longer VDR protein of 247 amino acids that exerts less transcriptional activity as compared to the wild type (CC) [22]. Several studies report that there is a significant association between the Fokl polymorphism and the risk of various types of cancer [26]. The Fokl polymorphism is considered to be an independent risk marker as it has no Linkage Disequilibrium with any of the other VDR polymorphisms $[27,28]$. Keeping in view the role played by vitamin $\mathrm{D}$ and VDR gene in various cancers, we aim to assess the contribution of vitamin D and Fokl polymorphism and its association with skin cancer in Kashmiri population.

\section{MATERIALS AND METHODS}

A total of 68 histopathologically confirmed newly diagnosed skin cancer patients attending the Department of Dermatology, Government Medical College (GMC), Srinagar, were included in this study. A pool of 65 normal healthy controls were also recruited from the same hospital that belonged to the same geographical area, ethnic background and were of matching sex and age group. The controls did not have a previous diagnosis of any type of cancer and had maintained a healthy life style. The subjects included farmers, labours, employers, household, medical personals and students. A written informed consent was obtained from each recruited subject and the study was approved by the ethical committee of GMC, Srinagar. Among the cases, 55.88\% were SCC, $39.70 \%$ included the BCC and $4.41 \%$ were melanoma. To avoid the experimental bias, melanoma type of skin cancer was excluded from the study. In cases, 58.82\% were males and $41.17 \%$ females and the control consisted of $53.84 \%$ male and $46.15 \%$ female. Also, $60.3 \%$ cases were in the age group of greater than 50 and $39.7 \%$ of the cases were in age group of less than 50 years. In controls, $58.46 \%$ were in age group of greater than 50 and $41.53 \%$ were in the age group of less than 50 . Out of 65 cases, $48.53 \%$ cases belonged to rural region and $51.47 \%$ cases belonged to urban region. In controls, $47.70 \%$ were from rural areas and $52.30 \%$ were from urban areas. Among the cases 25\% had a family history of cancer. Blood sample $(3 \mathrm{ml})$ was collected in EDTA coated vials from both the study groups for plasma collection and DNA extraction. Sample collection was done from the month of March to October every year to avoid seasonal variation of Vitamin D levels.

\section{Plasma vitamin D estimation}

Vitamin D status was measured by estimating concentrations of 25 -hydroxyvitaminD $(25(\mathrm{OH}) \mathrm{D})$ in the plasma. The circulating concentration of $25(\mathrm{OH})$ $\mathrm{D}$ in the range of $30-50 \mathrm{ng} / \mathrm{ml}$ is considered necessary for optimal health [29]. The healthy controls whose $25(\mathrm{OH}) \mathrm{D}$ levels were in the range of $27-53 \mathrm{ng} / \mathrm{ml}$ were included in the study. Plasma $25(\mathrm{OH}) \mathrm{D}$ levels 
were estimated by automated chemilumnescent microparticle immunoassay (CMIA) method by ARCHITECT25-OH vitamin D assay (Abbott laboratories illino is, USA Ref 3L52-25).

\section{Genotype Analysis}

Genomic DNA was extracted from the blood samples by using Quick-gDNA ${ }^{\mathrm{TM}}$ MicroPrepkit (Zymo Research, The Epigenetics Company, USA) according to given protocol. The concentration of extracted DNA was measured in a spectrophotometer at $260 \mathrm{~nm}$ wave length by using the formula: $\mathrm{DNA} \mu \mathrm{g} / \mathrm{ml}=\mathrm{A}_{260} \times 50 \mathrm{xdilution}$ factor. The purity of DNA was checked by using $A_{260} / A_{280}$. VDR Fokl genotype was analysed by PCR-RFLP using specific primers Forward 5'-AGCTGGCCCTGGCACTGACTCTGCTCT3'and Reverse 5'-ATGGAAACACCTTGCTTCTT CTCCCTC-3' for amplification of 265bp of DNA segment [30]. PCR amplification was carried out in a 50- $\mu$ l volume containing 50-150ng genomic DNA; IX PCR buffer containing $2 \mathrm{mM} \mathrm{MgCl}_{2}$ (Biotools, B\&M Labs, S.A. Madrid, Spain); 0.2mM dNTPs (Biotools, B\&M Labs, S.A. Madrid, Spain); 1.5Units of Taq polymerase; $2 \mathrm{pmol} / \mu \mathrm{l}$ of forward and reverse primers (Eurofins Genomics India Pvt Ltd). The PCR cycle conditions were as follows: Initial denaturation at $94^{\circ} \mathrm{C}$ for 10 minutes followed by 35 cycles of denaturation at $94^{\circ} \mathrm{C}$ for 45 seconds, annealing at $60^{\circ} \mathrm{C}$ for 45 seconds, extention for $72^{\circ} \mathrm{C}$ for 45 seconds and final extention at $72^{\circ} \mathrm{C}$ for 5 minutes. PCR products were verified on $2 \%$ agarose gel and analysed under a UV illuminator. The amplicons were digested with FastDigest Fokl restriction enzyme
(Thermo Scientific, (EU) Lithuania) $\left(1 \mathrm{U}\right.$ at $37^{\circ} \mathrm{C}$ for 15-20 minutes). DNA fragments were subjected to electrophoresis on a $3.5 \%$ agarose gel for resolution. Genotyping of the samples were confirmed via sequencing by Sanger method (SciGenom Labs Pvt Ltd, Cochin, Kerala).

\section{Statistical Analysis}

The vitamin D levels were analysed using independent t-test. The $\chi^{2}$-test was used to compare the allelic and genotypic frequencies. The association of the VDR genotype with the risk of skin cancer were estimated by computing the odds ratios (OR) and $95 \%$ confidence intervals $(95 \% \mathrm{CI})$. A p-value of $<0.05$ was considered as statistically significant. Statistical analysis was done using SPSS version 16.0 (SPSS, Inc., Chicago IL, USA).

\section{RESULT}

Vitamin D levels and Fokl polymorphism in VDR gene were evaluated in skin cancer cases. The calculated mean age of the skin cancer cases was $52.5 \pm 8.7$ years whereas it was $49.3 \pm 9.25$ years among the controls. The general characteristics of the studied subjects are given in Table 1. Interestingly higher number of SCC cases $(55.88 \%)$ followed by BCC $(39.70 \%)$ were observed when the skin cancer cases were classified into groups. Further, age distribution of cases showed that there was high incidence of skin cancer in the age group of $\geq 50$ years as compared to $<50$ years. The incidences of skin cancer were also found to be higher in males as compared to females. However, the

\begin{tabular}{|c|c|c|c|}
\hline Variables & $\begin{array}{c}\text { Cases }(n=68) \\
(\%)\end{array}$ & $\begin{array}{c}\text { Controls }(n=65) \\
(\%)\end{array}$ & $P$ value \\
\hline \multicolumn{4}{|l|}{ Gender } \\
\hline Male & $40(58.82)$ & $35(53.84)$ & 0.563 \\
\hline Female & $28(41.17)$ & $30(46.15)$ & \\
\hline \multicolumn{4}{|l|}{ Age } \\
\hline$\geq 50$ & $41(60.3)$ & $38(58.46)$ & 0.83 \\
\hline$<50$ & $27(39.7)$ & $27(41.53)$ & \\
\hline \multicolumn{4}{|l|}{$\geq 50$} \\
\hline \multicolumn{4}{|c|}{ Family History } \\
\hline Yes & $17(25.0)$ & $11(17.0)$ & 0.25 \\
\hline No & $51(75.0 \%)$ & $54(83.0)$ & \\
\hline \multicolumn{4}{|l|}{ Dwelling } \\
\hline Rural & $33(48.53)$ & $31(47.70)$ & 0.92 \\
\hline Urban & $35(51.47)$ & $34(52.30)$ & \\
\hline \multicolumn{4}{|l|}{ Skin Cancer } \\
\hline ScC & $38(55.88)$ & & \\
\hline $\mathrm{BCC}$ & $27(39.70)$ & & \\
\hline
\end{tabular}

$\mathrm{P}<0.05$ is considered as statistically significant, by chi square test. 
rates of incidences were comparable among of urban and rural cases.

\section{Plasma vitamin D levels}

The mean plasma 25(OH)D levels were significantly lower among skin cancer cases when compared to normal healthy controls $(21.05 \pm 9.67 \mathrm{ng} / \mathrm{ml}$ vs $38.88 \pm 7.29 \mathrm{ng} / \mathrm{ml}$, $\mathrm{P}<0.05$, Fig. 1). However, no significant difference was observed in 25(OH)D levels between SCC and BCC type of skin cancer (Table 2). In cases, the plasma 25(OH) D levels were found significantly lower among the age group of $\geq 50$ years as compared to $<50$ years $(\mathrm{P}<0.05)$. While, no significant difference in $25(\mathrm{OH}) \mathrm{D}$ levels was observed between the male and female cases (Table 2).

Table 2: Represents plasma 25(OH)D ng/ml levels in variables of skin cancer cases and controls

\begin{tabular}{|c|c|c|c|}
\hline \multirow[t]{2}{*}{ Variables } & \multicolumn{2}{|c|}{ Mean $\pm S D$ (range) } & \multirow[t]{2}{*}{ P-value } \\
\hline & Cases & Controls & \\
\hline SCC & $\begin{array}{c}21.58 \pm 10.17(06-40) \\
(n=38)\end{array}$ & $\begin{array}{c}38.88 \pm 7.29(27-53) \\
(n=65)\end{array}$ & $P<0.001$ \\
\hline $\mathrm{BCC}$ & $\begin{array}{c}20.76 \pm 8.91(08-37.7) \\
(n=27)\end{array}$ & $\begin{array}{c}38.88 \pm 7.29(27-53) \\
(n=65)\end{array}$ & $P<0.001$ \\
\hline$\geq 50$ & $\begin{array}{c}17.12 \pm 8.12(6 \text { to } 38) \\
(n=41)\end{array}$ & $\begin{array}{c}35.05 \pm 6.08(27 \text { to } 49) \\
(n=38)\end{array}$ & $P<0.001$ \\
\hline$<50$ & $\begin{array}{c}27.12 \pm 8.61(8 \text { to } 40) \\
(n=27)\end{array}$ & $\begin{array}{c}44.65 \pm 4.71(34 \text { to53 }) \\
(n=27)\end{array}$ & $P<0.001$ \\
\hline Males & $\begin{array}{c}21.11 \pm 10.77(7 \text { to } 40) \\
(n=40)\end{array}$ & $\begin{array}{c}39.17 \pm 7.28(28 \text { to53) } \\
(n=35)\end{array}$ & $P<0.001$ \\
\hline Females & $\begin{array}{c}20.96 \pm 8.02(6 \text { to } 36) \\
(n=28)\end{array}$ & $\begin{array}{c}38.55 \pm 7.42(27 \text { to } 50) \\
(n=30)\end{array}$ & $P<0.001$ \\
\hline
\end{tabular}

Data are represented as mean $\pm S D$, independent $t$-test. $P<0.05$ is

considered as statistically significant.

\section{Genotype distribution}

The distribution of genotypic and allelic frequencies of Fokl VDR polymorphism $(C>T)$ were compared between the skin cancer cases (diagnosed ones) and controls. The alteration of $\mathrm{C}$ to $\mathrm{T}$ allele in the start codon of translation site created a restriction site in the amplified region which was digested by Fokl restriction enzyme. The CC homozygote (wild) shows only one fragment of 265bp, while the TT homozygote (variant) with Fokl restriction site generated two fragments of 196bp and 69bp. The heterozygous (CT) genotype displayed three fragments of 265bp, 196bp and 69bp (Fig. 2). The frequency of CC, CT and TT genotypes among the cases were $33.82 \%$, $47.06 \%$ and $19.11 \%$ while in controls it was found to be $53.84 \%, 38.46 \%$ and $7.7 \%$ respectively Table 3 . The genotypic frequency of CC vs TT and CT+TT was found statistically significant among the cases when compared with normal healthy controls with a $\mathrm{p}$-value of 0.016 and $\mathrm{P}=0.02$ respectively. The mutant $\mathrm{T}$ allele was found to be a risk factor for skin cancer with $\mathrm{OR}=2.018$, 95\%CI1.205-3.379, $\mathrm{P}=0.007$. When the subjects were classified further into groups, it was observed that the frequency of CC, CT and TT genotypes in SCC type were $26.3 \%, 55.2 \%$ and $21 \%$ respectively and this pattern of distribution showed statistical significance among the SCC cases as compared to controls $(\mathrm{P}<0.05)$. While in BCC type the frequency of CC, CT and TT genotypes were $44.4 \%, 40.7 \%$ and $15 \%$ respectively. However no statistical significance was observed between the BCC

Table 3: Represents genotypic and allelic frequencies of Fok1 VDR gene among the skin cancer cases and controls and their association with risk of skin cancer

\begin{tabular}{|c|c|c|c|c|}
\hline $\begin{array}{l}\text { VDR } \\
\text { Polymorphism }\end{array}$ & Cases (\%) & $\begin{array}{c}\text { Controls }(n=65 \\
(\%)\end{array}$ & OR $(95 \% \mathrm{Cl})$ & $P$ value \\
\hline \multicolumn{5}{|l|}{ Fok-1 } \\
\hline Genotype & Skin & & & \\
\hline$C C(F F)$ & cancer $(n=68)$ & $35(53.84)$ & & \\
\hline$C T(F f)$ & $23(33.82)$ & $25(38.46)$ & 1.00 & \\
\hline$T T(f f)$ & $32(47.06)$ & $5(7.7)$ & $1.948(0.928-4.090)$ & 0.077 \\
\hline$C T+T T(F f+f f)$ & $13(19.11)$ & $30(46.15)$ & $3.957(1.243-12.594)$ & 0.016 \\
\hline Allele & $45(66.17)$ & & $2.283(1.133-4.597)$ & 0.02 \\
\hline$C(F)$ & & $95(73.07)$ & & \\
\hline$T(f)$ & $78(57.35)$ & $35(27.0)$ & $2.018(1.205-3.379)$ & 0.007 \\
\hline Genotype & $58(42.64)$ & & & \\
\hline$C C$ & $\operatorname{SCC}(n=38)$ & $35(53.84)$ & 1.00 & \\
\hline$C T$ & $10(26.3)$ & $25(38.46)$ & $2.8(1.12-7.0)$ & 0.025 \\
\hline$T T$ & $20(55.2)$ & $5(7.7)$ & $5.6(1.5-21)$ & 0.007 \\
\hline$C T+T T$ & $8(21.0)$ & $30(46.15)$ & $3.567(1.367-7.8)$ & 0.007 \\
\hline Allele & $28(76.6)$ & & & 0.003 \\
\hline C & & $95(73.07)$ & & \\
\hline $\mathrm{T}$ & $40(52.6)$ & $35(27.0)$ & $2.443(1.35-4.425)$ & \\
\hline Genotype & $36(47.3)$ & & & \\
\hline$C C$ & $B C C(n=27)$ & $35(53.84)$ & 1.00 & 0.612 \\
\hline$C T$ & $12(44.4)$ & $25(38.46)$ & $1.283(0.5-3.371)$ & 0.25 \\
\hline$T T$ & $11(40.7)$ & $5(7.7)$ & $2.33(0.537-10.14)$ & 0.411 \\
\hline$C T+T T$ & $4(15.0)$ & $30(46.15)$ & $1.46(0.6-3.6)$ & \\
\hline Allele & $15(55.5)$ & & & \\
\hline C & & $95(73.07)$ & & \\
\hline \multirow[t]{2}{*}{$\mathrm{T}$} & $35(64.8)$ & $35(27.0)$ & $1.473(0.747-2.90)$ & 0.262 \\
\hline & $19(35.1)$ & & & \\
\hline
\end{tabular}

$\mathrm{P}<0.05$ is considered as statistically significant, by chi square test. 
cases and controls. When the age group of $\geq 50$ years in cases of diagnosed subjects was evaluated, the frequency of mutant $T$ allele was found to be $41.46 \%$ compared to $26.31 \%$ among controls with $\mathrm{OR}=1.983,95 \%$ CI 1.01 $3.89, \mathrm{P}=0.045$. While in age group of $<50$ years, no significant difference was found between the cases and controls. In females, the frequency of mutant $T$ allele was $46.43 \%$ and $28.33 \%$ in cases and controls respectively and this observation showed a statistical significance of $T$ allele among the cases when compared to controls $(P=0.044)$. While, in males, no significant difference was observed between the cases and controls as shown in Table 4. Genotyping of the samples were confirmed via sequencing by Sanger method (SciGenom Labs Pvt Ltd, Cochin, Kerala) (Figs. 3 - 5).

\section{DISCUSSION}

Vitamin D plays an important role in various cancer related signaling pathways. Vitamin D induces

Table 4: Represents genotypic and allelic frequencies of Fok1 $V D R$ gene in age and gender variables of skin cancer cases and controls and their association with risk of skin cancer

\begin{tabular}{|c|c|c|c|c|}
\hline Variable & Cases & Control & OR (95\%Cl) & $P$ value \\
\hline Age $\geq 50$ & $(n=41)$ & $(n=38)$ & & \\
\hline Genotype & $15(36.6)$ & 21(55.26) & 1.00 & \\
\hline $\mathrm{CC}$ & $18(44)$ & $14(36.84)$ & $1.80(0.687-4.71)$ & 0.23 \\
\hline CT & $08(19.51)$ & $03(8)$ & $3.733(0.85-16.47)$ & 0.0713 \\
\hline$T T$ & $26(63.41)$ & $17(44.73)$ & $2.14(0.87-5.27)$ & 0.096 \\
\hline \multicolumn{5}{|l|}{$\mathrm{CT}+\mathrm{TT}$} \\
\hline \multicolumn{5}{|l|}{ Allele } \\
\hline C & $48(58.53)$ & $56(73.68)$ & & \\
\hline$T$ & $34(41.46)$ & $20(26.31)$ & $1.983(1.011-3.89)$ & 0.045 \\
\hline$<50$ & $(n=27)$ & $(n=27)$ & & \\
\hline Genotype & $8(29.6)$ & 14(51.85) & 1.0 & \\
\hline $\mathrm{CC}$ & $14(52)$ & $11(40.74)$ & $2.23(0.689-7.20)$ & 0.178 \\
\hline CT & $5(18.5)$ & $02(7.41)$ & $4.375(0.68-27.98)$ & 0.104 \\
\hline$T T$ & $19(70.37)$ & $13(48.14)$ & $2.56(0.835-7.83)$ & 0.096 \\
\hline \multicolumn{5}{|l|}{$\mathrm{CT}+\mathrm{TT}$} \\
\hline Allele & 30(55.5) & $39(72.2)$ & & \\
\hline C & $24(44.4)$ & $15(28)$ & $2.08(0.933-4.64)$ & 0.0714 \\
\hline \multicolumn{5}{|c|}{ 年 } \\
\hline Males & $(n=40)$ & $(n=35)$ & & \\
\hline Genotype & $14(35 \%)$ & $19(54.28 \%)$ & 1.0 & \\
\hline $\mathrm{CC}$ & $20(50 \%)$ & $14(40 \%)$ & $1.94(0.734-5.12)$ & 0.1795 \\
\hline$C T$ & $06(15 \%)$ & 02 (5.71\%) & $4.071(0.71-23.26)$ & 0.0982 \\
\hline$T T$ & $26(65 \%)$ & $16(45.71 \%)$ & $2.205(0.87-5.6)$ & 0.0932 \\
\hline \multicolumn{5}{|l|}{$C T+\mathrm{TT}$} \\
\hline \multicolumn{5}{|l|}{ Allele } \\
\hline C & 48 (60\%) & 52 (74.3\%) & & \\
\hline$T$ & $32(40 \%)$ & $18(25.71 \%)$ & $1.926(0.96-3.87)$ & 0.0641 \\
\hline Females & $(n=28)$ & $(n=30)$ & & \\
\hline Genotype & $9(32.14 \%)$ & $16(53.33 \%)$ & 1.0 & \\
\hline CC & $12(42.85 \%)$ & $11(36.66 \%)$ & $1.94(0.61-6.162)$ & 0.26 \\
\hline CT & $7(25 \%)$ & $3(10 \%)$ & $4.15(0.854-20.14)$ & 0.068 \\
\hline & $19(68 \%)$ & $14(46.66 \%)$ & $2.413(0.83-7.03)$ & 1.034 \\
\hline \multicolumn{5}{|l|}{$\mathrm{CT}+\mathrm{TT}$} \\
\hline \multicolumn{5}{|l|}{ Allele } \\
\hline C & $30(53.57 \%)$ & $43(71.66 \%)$ & & \\
\hline$T$ & $26(46.43 \%)$ & $17(28.33 \%)$ & $2.2(1.016-4.73)$ & 0.044 \\
\hline
\end{tabular}

${ }^{*} \mathrm{P}<0.05$ is considered as statistically significant, by chisquare test transcriptional activation or repression of target genes by binding to the VDR. In the epidermis, Hh and Wnt/ $\beta$ catenin are the two important vitamin $\mathrm{D}$ signaling pathways that play an important role in proliferation and differentiation of keratinocytes. VitaminD/ VDR inhibits the Hh pathway in keratinocytes by suppressing the expression of Shhandglil. In Wnt/ $\mathrm{K}$ catenin pathway, VitaminD/VDR binds to $\beta$-catenin and reduces its transcriptional activity. Therefore, VitaminD/VDR reduces the proliferation and induces the process of differentiation in keratinocytes thereby limiting their ability to induce tumors in the skin [20]. In keratinocytes, VitaminD/VDR regulates the proliferation in the basal layer of the epidermis and promotes sequential differentiation [31]. A low circulatory level of $25(\mathrm{OH}) \mathrm{D}$ is the main marker of

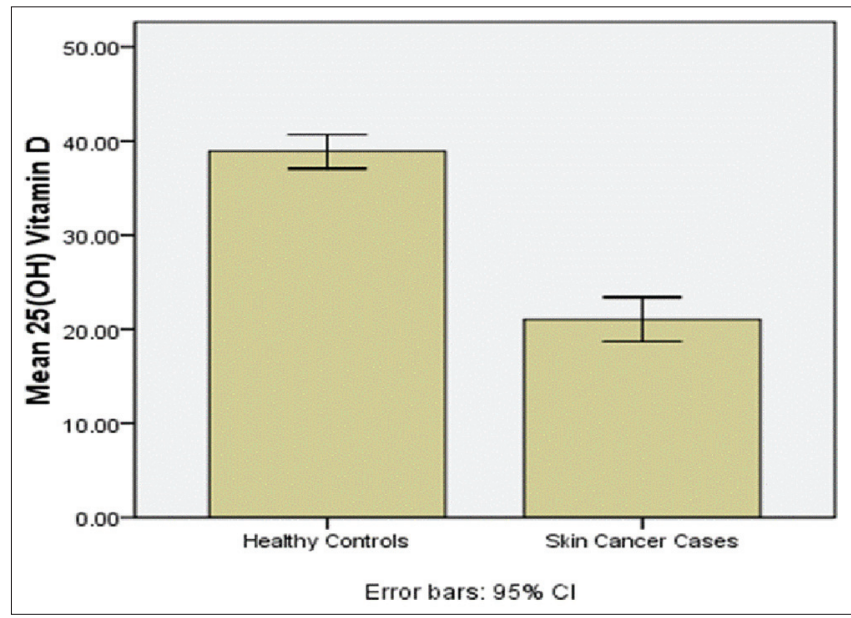

Figure 1: Represents the mean plasma 25(OH)D levels in skin cancer patients and controls.s Data are represented as mean $\pm 95 \%$ $\mathrm{Cl}$, independent t-test. $\mathrm{P}<0.05$ is considered as statistically significant.

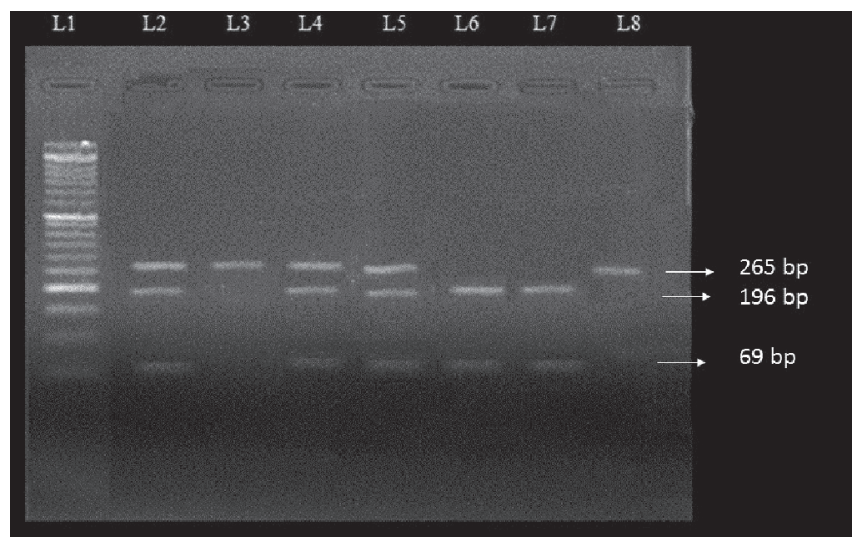

Figure 2: Representative gel picture showing PCR-based RFLP analysis of Fok1 VDR gene polymorphism on 3.5\% agarose gel. Lane no. 1 represents the 50bp DNA ladder. Lane no. 2, 4, 5 represents heterozygous genotype (three bands 265bp, 196bp and $69 \mathrm{bp}$ ). Lane no. 3 \& 8 represents homozygous wild genotype (one band 265bp). Lane no. $6 \& 7$ represents mutant homozygous genotype (two bands 196bp and 69bp). 


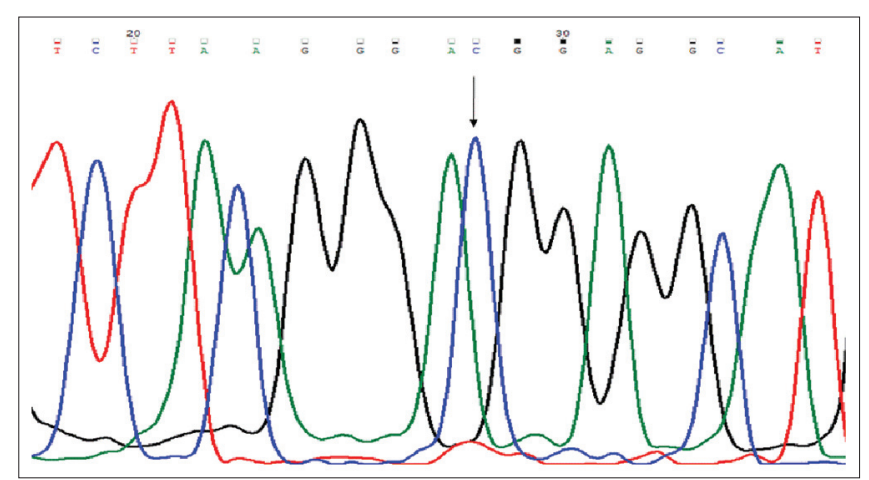

Figure 3: Representative electropherogram sequencing result of the Fok1 VDR gene polymorphism in exon 2, arrow indicates the presence of homozygous wild genotype (CC) at the polymorphic site.

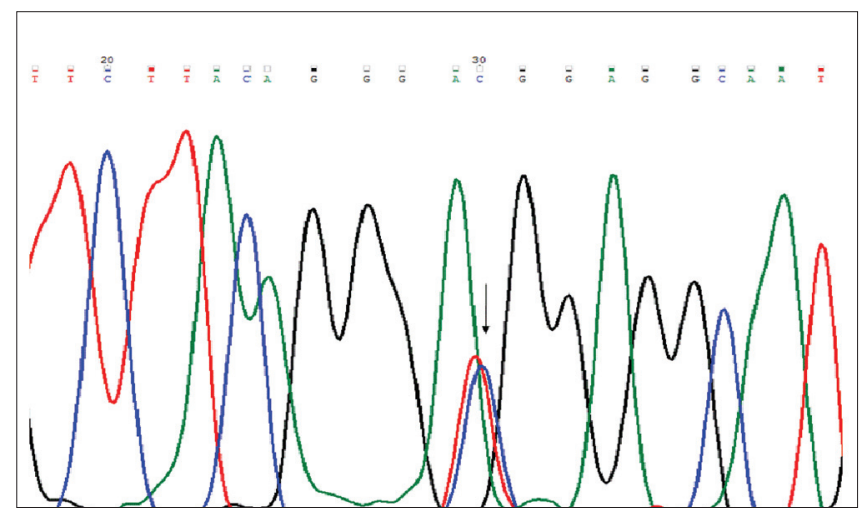

Figure 4: Representative electropherogram sequencing result of the Fok1 VDR gene polymorphism in exon 2, arrow indicates the presence of heterozygous genotype (CT) at the polymorphic site.

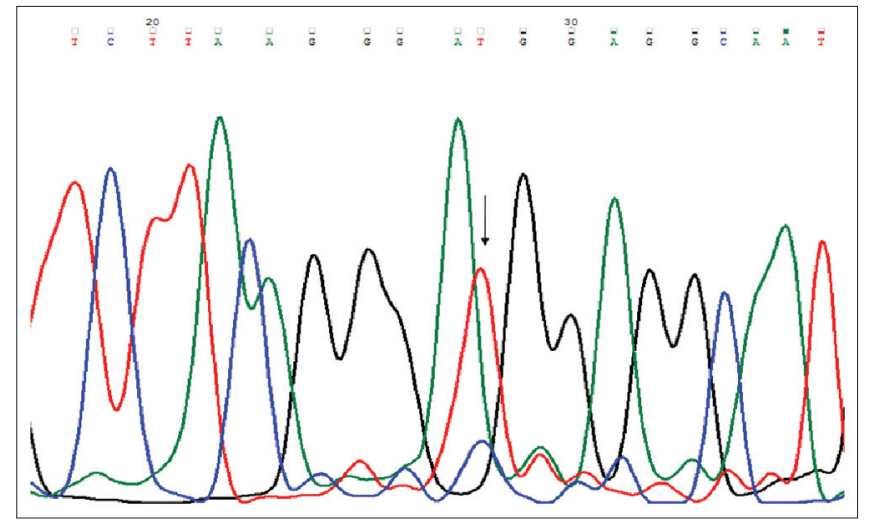

Figure 5: Representative electropherogram sequencing result of the Fok1 VDR gene polymorphism in exon 2, arrow indicates the presence of mutated homozygous genotype (TT) at the polymorphic site.

vitamin D deficiency. The limited exposure to sun is considered the main cause of vitamin D deficiency. However, prolonged sun exposure will not increase the vitamin D levels further, as Holick et al documented that human skin has the intrinsic ability of vitamin $\mathrm{D}$ production [32]. Harinarayan et al reported that the sunlight exposure between the hours lla.m. to 2p.m. will promote adequate vitamin $\mathrm{D}$ formation in the skin [33]. Usually, 20-30 minutes exposure in the sun two to four times a week is enough to maintain adequate levels of Vitamin D. The prolonged exposure to sunlight increases the risk of skin cancer as ultraviolet radiation in sufficient quantity can damage DNA, causing genetic mutations and results in abnormal cellular proliferation [34]. People aged $>50$ years are prone to develop vitamin $\mathrm{D}$ deficiency due to various risk factors such as decreased dietary intake, diminished sunlight exposure, reduced skin thickness, impaired intestinal absorption and impaired hydroxylation in the liver and kidney [35]. In the present study the plasma $25(\mathrm{OH}) \mathrm{D}$ levels were found to be significantly lower among skin cancer cases when compared to healthy controls $(21.05 \pm 9.67$ vs $38.8 \pm 7.29, \mathrm{P}<0.05)$. Several studies reported that the basal line of $25(\mathrm{OH}) \mathrm{D}$ levels were lower in skin cancer patients as compared to the control group. Asgari et al., reported an increased risk for BCC with higher prediagnostic serum 25(OH)D levels, adjusted for sun exposure, in a nested case control study [36]. Tang et al., reported that higher baseline $25(\mathrm{OH}) \mathrm{D}$ serum levels coincided with a decreased risk for NMSC [37]. Likewise Van der Pols et al., found that there is a reduced risk for SCC type of skin cancer, in those with a history of skin cancer and whose vitamin D levels $>75 \mathrm{nmol} / \mathrm{L}$ [38]. However, in the current study no significant difference was observed in plasma $25(\mathrm{OH}) \mathrm{D}$ levels between the SCC and BCC type of skin cancer. Plasma 25(OH)D levels were significantly lower among the cases of $\geq 50$ years age group as compared to $<50$ years. Tang et al., reported that elderly men with $25(\mathrm{OH}) \mathrm{D}$ levels $>75 \mathrm{nmol} / \mathrm{L}$ were associated with the decreased risk for non-melanoma type of skin cancer $(\mathrm{OR}=0.53, \mathrm{P}=0.026)$ [37]. In this study no significant difference was observed in the plasma $25(\mathrm{OH}) \mathrm{D}$ levels between the male and female patients. The rate of skin cancer incidence was observed higher in males as compared to female as unprotected sun exposure was found usually higher in males as compared to females. Several studies have evaluated the role of Fokl VDR polymorphism in skin cancer and have found that Fok-1 VDR gene polymorphism is as an important mediator in the development of skin cancer. A study reported that the Fokl ff genotype was positively associated with an increased risk for each type of skin cancer [38]. A meta-analysis conducted by Gandini et al., reported borderline significance with increased risk of $f$ allele in NMSC while the $f f$ genotype attributed to about $30 \%$ of the increased risk for the NMSC type of skin cancer [39]. Consistent with this studies, our 
findings suggest that Fokl VDR polymorphism was significantly associated with the risk of skin cancer. The frequency of homozygous mutant Fokl TT genotype and $T$ allele was found to be statistically significant among the skin cancer cases as compared to controls but statistical association was limited to SCC type. In SCC type of skin cancer, the genotypic frequency of both heterozygous CT and homozygous TT mutant Fokl polymorphism was found statistically significant in cases as compared to controls. This was consistent with a study conducted by Han et al., which showed the significantly positive association of Fokl polymorphism with SCC risk among the woman [40]. However, the association was found to be statistically in significant among BCC type of skin cancer. In $\geq 50$ years of age group, the frequency of mutant $T$ allele was observed to be statistically significant among the cases as compared to controls, while as, in $<50$ years of age group, no significant difference was found between the cases and controls. Similarly, among the males, no significant difference was found between the cases and controls, however, in females the frequency of mutant $T$ allele was found statistically significant among the cases as compared to controls. The present study supports the notion that vitamin D deficiency and Fokl VDR polymorphism may increase the risk of skin cancer and a strong association of Fokl polymorphism was observed with SCC type of skin cancer.

\section{CONCLUSION}

Vitamin D deficiency is found to be associated with different types of cancers including skin cancer. This study suggests a possible association of vitamin D deficiency and Fokl VDR polymorphism in skin cancer development, especially for SCC. Our study gives a strong impression that vitamin $\mathrm{D}$ has a protective effect against the development of skin cancer. However, there is need of independently large population-based prospective studies to validate our findings and to facilitate rigorous analyses of subgroups.

\section{ACKNOWLEDGEMENT}

The authors acknowledge the technical staff of the Diagnostic Laboratory Department of Biochemistry, Government Medical College, Srinagar especially Mr. Zahoor Ahmad. The authors also acknowledge the timely and precious help of Dr Kounsar Sideeq of Social and Preventive Medicine, Government Medical College Srinagar.

\section{STATEMENT OF HUMAN AND ANIMAL RIGHTS}

All procedures followed were in accordance with the ethical standards of the responsible committee on human experimentation (institutional and national) and with the Helsinki Declaration of 1975, as revised in 2008.

\section{STATEMENT OF INFORMED CONSENT}

Informed consent was obtained from all patients for being included in the study.

\section{REFERENCES}

1. Denzer N, Vogt T, Reichrath J. Vitamin D receptor (VDR) polymorphisms and skin cancer, A systematic review. DermatoEndocrinol. 2011;3:205-10.

2. Cakir Bö, Adamson P, Cingi C. Epidemiology and economic burden of nonmelanoma skin cancer. Facial Plastic Surgery Clinics of North America. 2012;20:419-22.

3. Dubas LE, Ingraffea A. Non melanoma skin cancer. Facial Plastic Surgery Clinics of North America. 2013;21:43-53.

4. Deo SV, Hazarika S, Shukla NA, Kumar S, Kar M, Samaiya A. Surgical management of skin cancers, Experience from a regional cancer centre in North India. Ind J Cancer. 2005;42:145-50.

5. Garcovich S, Colloca G, Sollena P, Andrea B, Balducci L, Cho WC, et al. Skin cancer epidemics in the elderly as an emerging issue in geriatric oncology. Aging Dis. 2017;8:643-61.

6. Adinarayan M, Krishnamurthy SP. Clinicopathological evaluation of nonmelanoma skin cancer. Indian J Dermatol. 2011;56:670-2.

7. Khullar G, Saikia UN, De D, Radotra BD. Nonmelanoma skin cancers: An Indian perspective. Indian J Dermatopathol Diagn Dermatol. 2014;1:55-62.

8. Teli MA, Khan NA, Darzi MA, Gupta M, Tufail A. Recurrence pattern in squamous cell carcinoma of skin cancer of lower extremities and abdominal wall (kangricancer) in Kashmir valley of Indian subcontinent, Impact of various treatment modalities. Ind J Dermatol. 2009;54:342-46.

9. Panda S. Non-melanoma skin cancer in India, Current scenario. Ind J Dermatol. 2010;55:373-78.

10. Rasool MT, Lone MM, Wani ML, Afroz F, Zaffar S, Mohib- ul Haq M. Cancer in Kashmir, India: Burden and pattern of disease. J Cancer Res Ther. 2012;8:243-6.

11. Faroog R, Amin S, Haamid B, Bhat AA, Wani HA, Majid S. CpG methylation in exon 1 of TCF4 gene as an early biomarker of gastric cancer. J Pharma Sci Rev Res Int. 2013;20:2 93-7.

12. Haamid B, Majid S, Hamid R, Farooq R, Wani HA, Shoib S, et al. A Polymorphism of XRCC3 gene in gastric cancer patients of Kashmir: A case control study. Europ J Cancer Prev. 2014;24:167- 75.

13. Bhat AA, Wani HA, Khan H, Arshid A, Farooq R, Haamid B, et al. Abberant promoter region hypermethylation of hmlh1 gene in esophageal cancer patients of Kashmir valley. Int J Engin Scien Invent. 2012:1:24-31.

14. Haq A, Sofi NY. Vitamin D and breast cancer: Indian perspective. Clin. Nutr. Exp. 2017;12:1-10.

15. Raman M, Milestone AN, Walters JR, Hart AL, Ghosh S. Vitamin D and gastrointestinal diseases: inflammatory bowel disease and colorectal cancer. Therap Adv Gastroenterol; 2011;4:49-62.

16. Mattoo AA, Khan H, Wani HA, Bhat AA, Mudasir H, Haamid B, et al. RAS Association Domain Isoform A Gene (RASSF1A) 
Hypermethylation in Ovarian Cancer Patients of Kashmir Valley. J Pak Med Stud. 2013;3:87-91.

17. Lefkowitz ES, Garland CF. Sunlight, vitamin D, and ovarian cancer mortality rates in US women. Int J Epidemiol. 1994;23:1133-36.

18. Malik RA, Promela M, Bhat AA Majid S. Vitamin D Receptor (VDR)gene polymorphim and type2 diabetes mellitus (T2DM)-A case-control study in Ethnic population of Kashmir valley. Adv Res Gastroentero Hepatol. 2017;4:555-648.

19. Deeb KK, Trump DL, Johnson CS. Vitamin D signalling pathways in cancer, potential for anticancer therapeutics. Nat Rev Cancer. 2007;7:684-700.

20. Bikle DD. The Vitamin D Receptor, A Tumor Suppressor in Skin, in Jorge Reichrath Sunlight, vitamin D and skin cancer, second ed. Land Bios Springer Scien. 2013;2:1-21.

21. Xu G, Mei Q, Zhou D, Wu J, Han L. Vitamin D receptor gene and aggrecan gene polymorphisms and the risk of intervertebral disc degeneration - a meta-analysis. PLoS One. 2012;7: e50243.

22. Gonzalez-Mercado A, Sanchez-Lopez JY, Regla-Nava JA, Gamez- Nava JI, Gonzalez-Lopez L, Duran-Gonzalez J, et al. Association analysis of vitamin D receptor gene polymorphisms and bone mineral density in postmenopausal Mexican-Mestizo women. Genet Mol Res. 2013;12:2755-63.

23. Alimirah F, Peng X, Murillo G, Mehta RG. Functional significance of vitamin D receptor Fok1 polymorphism in human breast cancer cells. PLos One. 2011;6:e16024.

24. He L, Wang M. Association of vitamin D receptor-a gene polymorphisms with coronary heart disease in Han Chinese. Int J Clin Exp Med. 2015;8:6224-29.

25. Fang Y, van Meurs JB, d'Alesio A, Jhamai M, Zhao H, Rivadeneira F, et al. Promoter and 3'-untranslated region haplotypes in the vitamin $\mathrm{D}$ receptor gene predispose to osteoporotic fracture, the Rotterdam study. Am J Hum Gent. 2005;77:807-23.

26. McCullough ML, Bostick RM, Mayo TL. Vitamin D gene pathway polymorphisms and risk of colorectal, breast, and prostate cancer. Annu Rev Nutr. 2009;29:111-32.

27. Uitterlinden SG, Fang Y, van Meurs JB, Pols HA, Van Leeuwen JP. Genetics and biology of vitamin D receptor polymorphisms. Gene. 2004;338:143-56.

28. Nejentsev S, Godfrey L, Snook H, Rance H, Nutland S, Walker NM, et al. Comparative high-resolution analysis of linkage disequilibrium and tag single nucleotide polymorphisms between populations in the vitamin D receptor gene. Hum. Mol. Genet. 2004;13:1633-9.
29. Norman AW, Bouillon R. Vitamin D nutritional policy needs a vision for the future. Exp Biol Med Maywood. 2006;235:1034-45.

30. Mohapatra S, Saxena A, Gandhi G, Koner BC, Ray PC. Vitamin D and VDR gene polymorphism (FokI) in epithelial ovarian cancer in Indian population. J Ovarian Res. 2013;6:37.

31. Bikle DD. Vitamin D and the skin: Physiology and pathophysiology. Reviews in endocrine \& metabolic disorders. 2012;13:3-19.

32. Holick MF, Chen TC, Lu Z, Sauter E. Vitamin D and skin physiology: a D-lightful story. J Bone Miner Res.in 2007;2:28-33.

33. Harinarayan CV, Holick MF, Michael F, Prasad MF, Vani PS, Himabindu G. Vitamin D status and sun exposure in India. Dermatoendocrinol. 2013;5:130-41.

34. Hoel DG, Berwick M, de Gruijl FR, Holick MF. The risks and benefits of sun exposure 2016. Dermato-endocrinology. 2016;8:e1248325.

35. Hennie CJP, Monique MS, Haralad JJV. Vitamin D deficiency, muscle function, and falls in elderly people. Am J Clin Nutr. 2002; 75:611-5

36. Asgari MM, Tang J, Warton ME, Chren MM, Quesenberry CP Jr, Bikle $\mathrm{D}$, et al. Association of prediagnostic serum vitamin $\mathrm{D}$ levels with the development of basal cell carcinoma. J Invest Dermatol. 2010;130:1438-43.

37. Tang JY, Parimi N, Wu A, Boscardin WJ, Shikany JM, Chren MM, et al. Inverse association between serum $25(\mathrm{OH})$ vitamin D levels and non-melanoma skin cancer in elderly men. Cancer Causes Control. 2010;21:387-91.

38. Vander Pols JC, Russell A, Bauer U, Neale RE, Kimlin MG, Green AC. Vitamin D status and nonmelanoma skin cancer risk independeant of time outdoors; 11-year prospective study in a Australian community. J Invest Dermatol. 2013;133:637-41.

39. Gandini S, Raimondi S, Gnagnarella P, Dore JF Maisonneuve P, Testori A. Vitamin D and skin cancer, a meta-analysis. Eur J Cancer. 2009;45,634-41.

40. Han J, Colditz GA, Hunter DJ. Polymorphisms in the MTHFR and VDR genes and skin cancer risk. Carcinogenesis. 2007;28:390-97.

Copyright by JasiyaQadir, et al. This is an open-access article distributed under the terms of the Creative Commons Attribution License, which permits unrestricted use, distribution, and reproduction in any medium, provided the original author and source are credited.

Source of Support: Nil, Conflict of Interest: None declared. 